\title{
Allelochemical defense against epibiosis in the macroalga Caulerpa racemosa var. turbinata
}

\author{
Sergey Dobretsov ${ }^{1}$, Hans-Uwe Dahms ${ }^{1}$, Tilmann Harder ${ }^{2}$, Pei-Yuan Qian ${ }^{1, *}$ \\ ${ }^{1}$ Department of Biology \& Coastal Marine Laboratory, Hong Kong University of Science and Technology, \\ Clear Water Bay, Kowloon, Hong Kong SAR, PR China \\ ${ }^{2}$ Institute of Chemistry and Biology of the Marine Environment (ICBM), University of Oldenburg, \\ Carl von Ossiezkystr. 9-11, 26111 Oldenburg, Germany
}

\begin{abstract}
The abundance and diversity of microorganisms on the surface of the tropical green macroalga Caulerpa racemosa var. turbinata and the effect of algal surface and waterborne compounds on fouling organisms were investigated both in laboratory and field experiments. As shown via electron microscopic enumeration, the abundance of epibiotic bacteria and diatoms on algal frond surfaces was not significantly different from the reference biofilms harvested from stones in the C. racemosa habitat. The analysis of Terminal Restriction Fragment Length Polymorphism of DNA from algal surface-associated bacterial communities revealed that despite a similar abundance of these bacteria, the community profile on algal frond surfaces differed significantly from that of inanimate, undefended substrates. These results suggest that the alga regulate the occurrence of certain bacterial ribotypes. This result was in accordance with the fact that different bacterial communities formed on the artificial substrata (i.e. Petri dishes) placed in the C. racemosa habitat and alga-free control sites. Neither C. racemosa conditioned seawater (CCW) nor hexane surface extracts affected the growth of bacterial isolates from biofilms. However, only CCW exhibited a toxic effect on the larvae of the fouling polychaete Hydroides elegans, and evoked abnormal larval development in a concentration-dependent fashion. At sublethal concentrations, the $<1 \mathrm{kD}$ fraction of $\mathrm{CCW}$ inhibited the larval settlement of $H$. elegans and the bryozoan Bugula neritina. Caulerpenyne, the prominent bioactive metabolite in the genus Caulerpa, was not detected in CCW by chromatographic procedures. Our data suggest that waterborne compounds other than caulerpenyne are involved in the chemical defense of the alga C. racemosa.
\end{abstract}

KEY WORDS: Caulerpa racemosa $\cdot$ Algae $\cdot$ Microbial communities $\cdot$ Larval settlement $\cdot$ Epibiosis · Antifouling $\cdot$ Chemical defense

\section{INTRODUCTION}

Many marine algae have evolved efficient strategies to control epibiosis either chemically by producing defensive compounds (Nylund \& Pavia 2003, Bhadury \& Wright 2004, Fusetani 2004) and/or physically by sloughing and secreting mucus (Steinberg et al. 1997, Nylund \& Pavia 2005). It has been shown that macroalgae produce antibacterial (Devi et al. 1997, Hellio et al. 2000, 2001), antifungal (König \& Wright 1997, Hellio et al. 2000), and antilarval compounds (De Nys et al. 1995, Schmitt et al. 1995, Walters et al. 1996, Harder \&
Qian 2000, Hellio et al. 2004). Antifouling metabolites of red and brown algae, such as diterpene alcohols (Schmitt et al. 1995), brominated phenols (Phillips \& Towers 1982), sesquiterpenoids (de Nys et al. 1998), and halogenated furanones (Steinberg et al. 1997, 1998) repel propagules or inhibit growth of microorganisms. Contrary to brown and red algae, comparative allelochemical studies of green algae are rare (Mtolera \& Semesis 1996, Walters et al. 1996, Harder \& Qian 2000, Harder et al. 2004). In general, antifouling compounds from marine algae cover a small molecular size range of relatively unpolar metabolites, which stay 
in close association with their site of production. These physical-chemical attributes have been suggested to be critical for bioactive substances to function as natural antifoulants in the absence of strong boundarylayer effects (Steinberg et al. 1998, 2001, 2002).

Field observations in Hong Kong waters from 1999 to 2005 revealed that the fronds of the green macroalga, Caulerpa racemosa (J. Agardh) var. turbinata (Eubank, 1946) (later Caulerpa racemosa), were conspicuously free of epibiotic macroorganisms throughout the year (authors' obs.), indicating effective mechanisms of antifouling control. The alga C. racemosa is native to the tropics, and thus subject to intense herbivore and fouling activity. The natural products of at least 14 species of Caulerpa from around the world have been studied in detail (Paul \& Fenical 1986, Faulkner 1995). Most species produce the water-soluble sesquiterpene caulerpenyne (CYN) (Paul et al. 2006), which can reach up to $1.3 \%$ of algal dry mass (Aguilar-Santos 1970, Jung et al. 2002). As CYN is the most predominant toxin, the toxicity of Caulerpa algae is attributed to the production of this compound (Meyer \& Paul 1992, Schroeder et al. 1998). For instance, CYN exhibits antibiotic activity (Paul \& Fenical 1986), and has cytotoxic effects on eggs of some marine mammals (Pesando et al. 1996, Pedrotti \& Lemée 1999). However, the effect of Caulerpa metabolites on ecologically relevant marine organisms has only been studied in a few cases (Selvi \& Selvaraj 2000, Smyrniotopoulos et al. 2003, Freile-Pelegrin \& Morales 2004, Paul et al. 2006). It is also believed that CYN is present at the Caulerpa frond surface but is quickly degraded in the presence of seawater (Amade \& Lemée 1998).

During 2 severe algal blooms in the summers of 2004 and 2005, we collected Caulerpa racemosa to conduct a series of experiments in order to elucidate whether algal metabolites, particularly CYN, affect both microbial and macroscopic colonizers on algal surfaces and nearby substrata. These studies consisted of a comparison of the abundance of microorganisms on the surface of C. racemosa fronds and stones in close proximity to the alga. Additionally, we also investigated a long range effect of waterborne compounds of C. racemosa on the formation of microbial communities on artificial substrata in the Caulerpa habitat and $50 \mathrm{~m}$ away from it. We used molecular fingerprinting techniques to analyze microbial community patterns; assessed the effects of both waterborne and surfaceattached algal metabolites on bacterial growth, larval development and settlement of the fouling polychaete, Hydroides elegans, and the bryozoan, Bugula neritina, in laboratory bioassays. Finally, we analyzed the waterborne and surface-attached algal metabolites for the presence of CYN by flash chromatography and GC-MS.

\section{MATERIALS AND METHODS}

Collection of algae. Caulerpa racemosa was collected from the seafloor at a depth of 2 to $3 \mathrm{~m}$ next to the pier of the Coastal Marine Laboratory of the Hong Kong University of Science and Technology, Port Shelter Bay $\left(22^{\circ} 19^{\prime} \mathrm{N}, 114^{\circ} 16^{\prime} \mathrm{E}\right)$ in June and July 2004 (for microbial enumeration, preparation of the conditioning of seawater and bacterial community analysis) and in July 2005 (for isolation and identification of CYN, isolation of surface-associated molecules). In all cases, algal holdfasts were carefully detached without damaging the fronds. The algal tissue volume (measured by water displacement) and the algal wet weight were determined immediately after collection. The algae were carefully washed with $0.22 \mu \mathrm{m}$ filtered and autoclaved seawater (AFSW) to flush away external debris.

Scanning electron microscopy. Small algal fronds $(\mathrm{n}=5)$ and reference substrata (small flat stones) in the proximity ( 5 to $15 \mathrm{~cm}$ away from Caulerpa stands) of dense aggregations of $C$. racemosa $(\mathrm{n}=5)$ were fixed in $5 \%$ buffered formalin and dehydrated in an increasing ethanol series, dried by the critical point procedure, and sputtered with gold (see Dobretsov \& Qian, 2002 for details). The specimens were examined with a JEOL 6300F $(70 \mathrm{eV})$ scanning electron microscope (SEM) at magnifications of 1000 and 5000 $x_{i}$ bacteria and diatoms were counted in 10 selected fields of view (8000 and $300 \mu^{2}$ respectively) per replicate.

Analysis of bacterial community patterns. Biofilms were harvested from algal surfaces and artificial substrates (i.e. polystyrene Petri dishes) by surface swabbing according to Liu et al. (1997). Substrates used in the investigation were: (1) algal blades and stones, with surface areas of about $20 \mathrm{~cm}^{2}$, in close proximity ( 5 to $10 \mathrm{~cm})$ to the algae $(\mathrm{n}=5) ;(2) 24 \mathrm{~h}$ old biofilms developed on Petri dishes, with surface areas of $70 \mathrm{~cm}^{2}(\mathrm{n}=$ 10 ), at a depth of $2 \mathrm{~m}$ in the C. racemosa microhabitat and about $50 \mathrm{~m}$ away from it in an area without this alga (reference microhabitats: $\mathrm{n}=10$ ). The biofilm swabs were suspended in $0.8 \mathrm{ml}$ of lysis buffer $(1 \%$ Triton X-100, $20 \mathrm{mM}$ Tris- $\mathrm{HCl}$ at $\mathrm{pH}$ 8.2). The amplification of $16 \mathrm{~S}$ rDNA was performed with the PCR primer pair: 341F (5'-CCTACGGGAGGCAGCAG-3') and 926R-Fam (5'-CCGTCAATTCCTTTRAGTTT-3') (Amann et al. 1990, Lee et al. 1993). The 926R primer was labeled at the $5^{\prime}$ end with 6-carboxy fluorescein (FAM) dye. The thermocycling conditions were as follows: $95^{\circ} \mathrm{C}$ for $2 \mathrm{~min}(1 \mathrm{cycle}) ; 95^{\circ} \mathrm{C}$ for $30 \mathrm{~s}$ ( 15 cycles), $60^{\circ} \mathrm{C}$ for $3 \mathrm{~min}$ and $72^{\circ} \mathrm{C}$ for $3 \mathrm{~min}$. The annealing temperature started at $60^{\circ} \mathrm{C}$ and was reduced to $45^{\circ} \mathrm{C}$ in increments of $1{ }^{\circ} \mathrm{C} \mathrm{cycle}^{-1} ; 10$ cycles of $95^{\circ} \mathrm{C}$ for $30 \mathrm{~s}, 45^{\circ} \mathrm{C}$ for $3 \mathrm{~min}$ and $72^{\circ} \mathrm{C}$ for $3 \mathrm{~min}$; and $72^{\circ} \mathrm{C}$ for $10 \mathrm{~min}$. Amplified DNA ( $4 \mu \mathrm{l}$ of PCR mixtures) was visualized by gel electrophoresis on a $1.5 \%$ agarose gel in Tris- 
acetate-ethylenediaminetetraacetic acid (TAE) buffer. Fluorescently labeled PCR products were purified with the Wizard ${ }^{\circledR}$ PCR preps DNA purification system (Promega) according to the manufacturer's protocol. Purified amplicons were digested with 20U MspI (Boehringer Mannheim Biochemicals) at $37^{\circ} \mathrm{C}$ for $6 \mathrm{~h}$. Ten $\mu \mathrm{l}$ of digested products were mixed with $0.5 \mu$ of internal size standard (ET550-R, Amersham Biosciences). This mixture was denatured for 2 min at $95^{\circ} \mathrm{C}$ and immediately chilled on ice prior to capillary electrophoresis on a MegaBACE ${ }^{\mathrm{TM}}$ genetic analyzer (Amersham Biosciences) operated in the genotyping mode. After the electrophoresis, the length of the fluorescently labeled terminal restriction fragments (TRFs), was determined by comparison with internal size standards by using the 'Fragment Profiler' software (Amersham Biosciences). The lengths of TRFs obtained by the analyzer were rounded up to the nearest integral values. Peaks that were less than $1.5 \mathrm{bp}$ apart from a larger peak were classified as its 'shoulders' and thus eliminated (Dunbar et al. 2001). For each sample, peaks over a threshold of 50 fluorescence units (Blackwood et al. 2003) and whose peak heights contributed for at least $1 \%$ to the integrated height (Buchan et al. 2003, Luna et al. 2006) were used for analysis. Terminal fragments $<35$ and $>500$ bp were excluded from the analysis to avoid detection of primers and uncertainties of size determination.

Preparation of Caulerpa-conditioned seawater (CCW). The green alga $C$. racemosa was incubated at $25^{\circ} \mathrm{C}$ for $1 \mathrm{~h}$ in untreated seawater from the collection site (1:1 gravimetric ratio: original concentration). Seawater from a reference site (an area $50 \mathrm{~m}$ away from the Caulerpa stand) served as the control. After incubation, CCW and the seawater control were filtered through $0.22 \mu \mathrm{m}$ membranes (Millipore) and used directly in disc diffusion assays, larval bioassays, or were subjected to ultrafiltration in an ice bath (YM100, YM-10, YM-1: Millipore). This procedure yielded filter residues of 100, 10 and $1 \mathrm{kD}$ molecular weight cut-off and a $<1 \mathrm{kD}$ filtrate. Residues were redissolved in AFSW to the original volume of CCW. The filtrates and residues were immediately assayed for the ability to inhibit the metamorphosis of Hydroides elegans larvae. The $<1 \mathrm{kD}$ fraction was stored at $-20^{\circ} \mathrm{C}$ and used for the identification and isolation of CYN.

Isolation of surface-attached metabolites. Surfaceassociated metabolites from the alga were extracted using the technique of De Nys et al. (1998). For this $206 \mathrm{~g}$ (wet weight) of the alga was dip-extracted in $100 \mathrm{ml}$ of hexane (Fisher Scientific) for $30 \mathrm{~s}$. The effect of the solvent on epithelial cells was investigated by an epifluorescence microscope at $1000 \times$ magnification (Zeiss Axiophot). The hexane extracts were concentrated under vacuum at $29^{\circ} \mathrm{C}$, re-dissolved in dimethyl sulfoxide (DMSO) (Sigma) and stored until use at $-20^{\circ} \mathrm{C}$. In order to use extracts at surface concentrations in the bioassays corresponding to natural surface concentrations of metabolites, the ratio of surface area:wet weight was calculated for small algal pieces. Based on this ratio the total area of extracted algae was calculated. Prior to the experiments, the hexane extract was diluted with AFSW in order to obtain the algal surface level concentrations (SLC) in the multiwell plates.

Isolation and identification of CYN. CYN was purified from algae according to Amade \& Lemée (1998). The compound was detected at $254 \mathrm{~nm}$ and identified on the basis of its characteristic UV spectrum in a mixture of hexane and ethyl acetate 95:5, with a $\lambda_{\max }$ of $257 \mathrm{~nm}$ and shoulders at 270 and $285 \mathrm{~nm}$. In order to determine the presence of CYN in the $<1 \mathrm{kD}$ fraction of $\mathrm{CCW}, 200 \mathrm{ml}$ of $\mathrm{CCW}$ were extracted with $5 \mathrm{ml}$ of hexane:ethyl acetate $(95: 5 \%)$ for $24 \mathrm{~h}$ at $0^{\circ} \mathrm{C}$. Five replicated samples of CCW were used. The extract was concentrated under vacuum and redissolved in ethanol (25 $\mu \mathrm{g} \mathrm{ml}^{-1}$ ). The concentrate $(5 \mathrm{ml})$ was filtered through a silica cartridge (Clean SPE Si, Alltech Assoc.) with $10 \mathrm{ml}$ of hexane:ethyl acetate (95:5\%) followed by $10 \mathrm{ml}$ of ethyl acetate (100\%). Both fractions were concentrated under vacuum and subjected to high performance liquid chromatography (HPLC, Hewlett-Packard HP1100) on a silica column (LiChrospher Si 100, Merck ${ }^{\circledR}$; particle size $=5 \mu \mathrm{m}$; pore size $100 \AA$ ) and elution with hexane:ethyl acetate (95:5\%) with UV detection at $254 \mathrm{~nm}$. All fraction peaks were concentrated under vacuum and subsequently analyzed by a coupled GC-MS with electron impact ionization (Varian CP-3800, ion trap Varian-4000). Analogously, we determined the presence of CYN in the hexane extracts (surface-attached metabolites). The extracts were concentrated under vacuum and the presence of CYN in the extracts was analyzed by GCMS. In order to determine the detection limit of CYN by HPLC, different concentrations of CYN in hexane:ethyl acetate $(95: 5 \%)$ ranging from $1 \mathrm{mg} \mathrm{ml}^{-1}$ to $0.01 \mu \mathrm{g} \mathrm{ml}^{-1}$ were analyzed. The chromatographic conditions were the same as described above.

Disc diffusion bioassay. Antibacterial activity of Caulerpa extracts was tested against bacterial strains belonging to $\gamma$-Proteobacteria (Vibrio gallicus UST030701-074, V. parahaemolyticus UST030701-224, Marinobacter sp. UST040317-15, M. flavimaris UST040317-005, Pseudoalteromonas flavipulchra UST040317-169, Alteromonas marina UST030701-337, Psychrobacter pacificensis UST040317-196, and Pelagiobacter variabilis UST040317-109), $\alpha$-Proteobacteria (Ruegeria atlantica UST030701-046 and Erythrobacter flavus UST030701-080), Cytophaga-FlexibacterBacteroides (Flexibacter sp. UST991130-045 and Tenacibaculum mesophilum UST991130-047), and to the 
Firmicutes groups (Bacillus atrophaeus UST040317111, B. pumilus UST040317-29, B. thuringiensis UST040317-179, and Staphylococcus sp. UST040317-166). These isolates were obtained from the Bacterial Culture Collection of the Hong Kong University of Science and Technology (numbers indicate the sample identification) and isolated from a $7 \mathrm{~d}$ old subtidal biofilm from the region of the investigation. Bacteria were grown in marine broth $(3 \%$ yeast extract, $5 \%$ peptone in artificial seawater) at $37^{\circ} \mathrm{C}$ for $24 \mathrm{~h}$. Aliquots of $200 \mu \mathrm{l}$ of cell culture $\left(10^{6} \mathrm{CFU} \mathrm{ml}{ }^{-1}\right)$ were plated onto Petri dishes containing bacteriological agar No. 1 (Oxoid). Sterile paper discs of $6 \mathrm{~mm}$ diameter (Whatman No. 1) were loaded with $20 \mathrm{\mu l}$ of $\mathrm{CCW} \operatorname{disc}^{-1}$, or appropriate amounts of surface attached metabolites in order to obtain $0.5 \times, 1 \times$ and $2 \times$ SLC concentrations. The paper discs were air dried and placed on inoculated agar plates. Bactericidal effects were determined after $24 \mathrm{~h}$ of incubation at $30^{\circ} \mathrm{C}$ by measuring the diameter of the inhibition zone. All measurements were performed in triplicates and in 3 repeats. Control discs were prepared with seawater and hexane (both at $20 \mu \mathrm{g} \mathrm{disc}^{-1}$ ).

Larval culture. Adults of the polychaete tubeworm, Hydroides elegans, and the bryozoan, Bugula neritina, were collected from submerged rafts of a fish farm in Yung Shue O, Hong Kong $\left(114^{\circ} 21^{\prime}\right.$ E, $\left.22^{\circ} 24^{\prime} \mathrm{N}\right)$. Larval cultures were prepared and maintained according to Pechenik \& Qian (1998). Competent larvae of H. elegans and $B$. neritina were used for settlement bioassays (Bryan et al. 1997). Competence of $H$. elegans larvae was determined by their morphology and by a bioassay with a settlement inducer, the phosphodiesterase inhibitor 3-isobutyl-methylxanthine (IBMX) at $10^{-4} \mathrm{M}$ solution in AFSW (Pechenik \& Qian 1998).

Larval development assay. The laboratory bioassay was performed 3 times on different larval batches with replication $(\mathrm{n}=5)$ in multiwell polystyrene dishes (\#3047, FALCON), each containing 20 early trochophore larvae of Hydroides elegans (which hatched no longer than $15 \mathrm{~min}$ before the onset of the experiment) in $1 \mathrm{ml}$ of CCW with dilutions of Caulerpa racemosa in AFSW at $1 \times, 0.2 \times, 0.1 \times$, and $0.01 \times$. The percentage of mortality and abnormal development (indicated by asymmetries, failure of ciliary band formation, and intrusions of ciliary bands) was determined after $24 \mathrm{~h}$. During the assay, larvae were not fed.

Larval settlement assay. The laboratory bioassay was repeated 6 times with different larval batches in polystyrene dishes each containing 20 competent larvae of Bugula neritina or Hydroides elegans and CCW $(0.01 \times)$ or surface-attached metabolites $(0.25 \times, 0.5 \times, 1 \times$ and $2 \times$ SLC) as well as CYN (concentration $=0.006-1.2 \mathrm{mg}$ $\mathrm{ml}^{-1}$ ). In all bioassays, AFSW was used as a positive control. In bioassays with larvae of $H$. elegans, $10^{-4} \mathrm{M}$ IBMX (see above) in AFSW was used as an artificial stimulator for larval settlement (Dobretsov \& Qian 2002). Prior to the experiments, $H$. elegans larvae were treated with IBMX at $10^{-4} \mathrm{M}$ solution in AFSW for $1 \mathrm{~h}$, washed in AFSW, and subsequently used for the assays. Larval settlement assays for $H$. elegans were run at $28^{\circ} \mathrm{C}$ under continuous illumination for $24 \mathrm{~h}$, and for $1 \mathrm{~h}$ without illumination in the case of $B$. neritina. After these periods, dishes were emptied and the settled juveniles were counted under the dissecting microscope. Mortality and settlement values were transformed into percentages.

Statistical analysis. The densities of bacteria and diatoms on the surface of algae and artificial substrates were compared by a Student $t$-test. The percent values of larval attachment in response to experimental treatments were arcsine-transformed. To improve the arcsine-transformation, replicates with no attachment were given the value of $(4 \times \mathrm{n})^{-1}$, where $\mathrm{n}$ is the number of larvae in a single replicate (Zar 1999). The homogeneity and normality of the data were analyzed with Levene's and Shapiro-Wilk's $W$ test, respectively, at a confidence level of $95 \%$. Data were analyzed by 1-way ANOVA. LSD post-hoc multiple comparison tests or multiple pair-wise comparisons versus negative controls (Dunnett's test) were employed at the $95 \%$ confidence level (Conover \& Iman 1981). Statistical calculations were performed with the software package Statistica (StatSoft). TRF patterns of different bacterial community DNA samples were subjected to cluster analysis where Bray-Curtis similarities produced a similarity matrix based on the total number of TRFs observed in all samples compared to the presence or absence of these TRFs in individual samples. For the construction of a dendrogram that demarcated the similarity of microbial communities on the gels, group average linkage in a hierarchical, agglomerative clustering algorithm was performed using the PRIMER program (Plymouth Marine Laboratory).

\section{RESULTS}

\section{Enumeration of microbial epibionts on Caulerpa racemosa}

Scanning electron microphotographs proved the presence of attached bacteria and diatoms on the algal surface. The bacterial abundances on the algal surface were slightly but not significantly lower (Student $t$-test, $\mathrm{df}=8 ; t=0.69, \mathrm{p}>0.05$ ) than those on the surface of reference substrata (i.e. stones of the ambient environment) (Fig. 1). The diatom abundance was not significantly different (Student $t$-test, $\mathrm{df}=8 ; t=0.31, \mathrm{p}>0.05$ ) either. No invertebrate juveniles were found on the algal surface. 


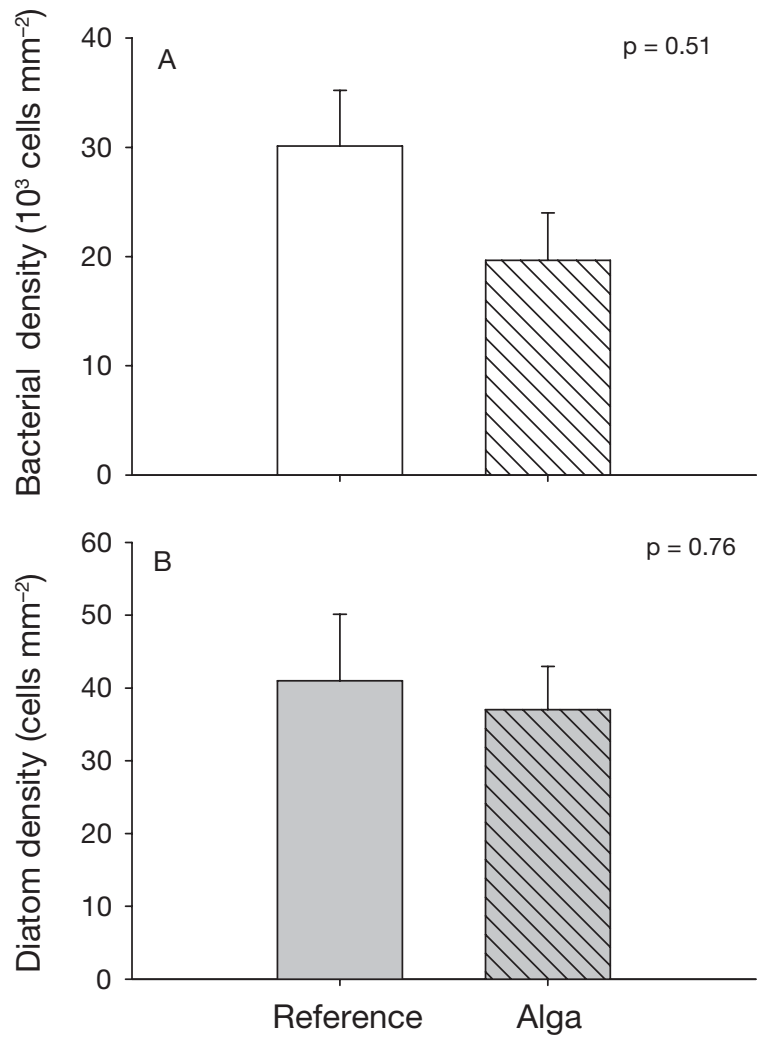

Fig. 1. Densities of (A) bacteria and (B) diatoms on stones (reference) and on frond surfaces of Caulerpa racemosa (alga). Bacteria and diatoms were counted using scanning electron microscopy at 5000 and $1000 \times$ magnification, respectively. Samples were taken from the seafloor next to the pier of the Coastal Marine Lab of the Hong Kong University of Science and Technology, Port Shelter Bay, June 2004. Data plotted are means $(n=5) \pm S E$. $p$-values ( $t$-test) are given in each panel

\section{Bacterial community profiles on Caulerpa racemosa and reference surfaces}

The analysis of Terminal Restriction Fragment Length Polymorphism (T-RFLP) based on 113 discernible TRFs revealed that the bacterial community profiles on the surface of Caulerpa racemosa were different from those on the inanimate reference surfaces (i.e. stones in the ambient environment) (Table 1). Cluster analysis of a similarity matrix revealed that the profiles of bacterial communities on replicate algal surfaces were highly similar, forming a cluster distantly related to the bacterial communities on replicate reference surfaces (Fig. 2). The lowest number of TRFs (i.e. bacterial ribotypes) were recorded from the reference surface, while communities which developed on the surfaces of Caulerpa racemosa fronds had a higher number of bacterial
Table 1. Terminal restriction fragment length polymorphism profiles of bacterial communities derived from surface of Caulerpa racemosa and from stones of ambient environment at a reference site. Presence and fragment sizes (bps) of individual terminal restriction fragments (TRFs) denoted as follows: $\mathrm{X}^{\mathrm{a}}{ }^{\mathrm{a}}$ : present in 3 out of 3 replicates; ${ }^{\mathrm{b}}$ : present in 2 out of 3 replicates; presence in 1 out of 3 replicates omitted; -: absence of particular TRFs in a given biofilm

\begin{tabular}{|c|c|c|}
\hline $\begin{array}{l}\text { TRF } \\
\text { (bps) }\end{array}$ & $\begin{array}{l}\text { Reference } \\
\text { (rock) }\end{array}$ & Caulerpa \\
\hline 62 & - & $\mathrm{X}^{\mathrm{b}}$ \\
\hline 71 & $\mathrm{X}^{\mathrm{b}}$ & $\mathrm{X}^{\mathrm{b}}$ \\
\hline 76 & - & $\mathrm{X}^{\mathrm{b}}$ \\
\hline 80 & $\mathrm{X}^{\mathrm{a}}$ & - \\
\hline 91 & - & $\mathrm{X}^{\mathrm{a}}$ \\
\hline 92 & $\mathrm{X}^{\mathrm{a}}$ & - \\
\hline $96-123$ & - & $\mathrm{X}^{\mathrm{a}}$ \\
\hline 127 & $\mathrm{X}^{\mathrm{a}}$ & $\mathrm{X}^{\mathrm{b}}$ \\
\hline 128 & $X^{a}$ & - \\
\hline $131-182$ & - & $\mathrm{X}^{\mathrm{a}}$ \\
\hline $183-205$ & $\mathrm{X}^{\mathrm{a}}$ & - \\
\hline 206 & - & $\mathrm{X}^{\mathrm{b}}$ \\
\hline $207-209$ & $\mathrm{X}^{\mathrm{b}}$ & - \\
\hline $217-247$ & - & $\mathrm{X}^{\mathrm{b}}$ \\
\hline 248 & $\mathrm{X}^{\mathrm{b}}$ & $\mathrm{X}^{\mathrm{a}}$ \\
\hline 249 & $\mathrm{X}^{\mathrm{b}}$ & $\mathrm{X}^{\mathrm{a}}$ \\
\hline $263-298$ & - & $\mathrm{X}^{\mathrm{b}}$ \\
\hline 299 & $\mathrm{X}^{\mathrm{a}}$ & - \\
\hline $300-312$ & - & $X^{a}$ \\
\hline 314 & $\mathrm{X}^{\mathrm{a}}$ & - \\
\hline 315 & $\mathrm{X}^{\mathrm{b}}$ & $\mathrm{X}^{\mathrm{a}}$ \\
\hline 369 & $\mathrm{X}^{\mathrm{b}}$ & \\
\hline 370 & - & $\mathrm{X}^{\mathrm{b}}$ \\
\hline 371 & $X^{a}$ & $\mathrm{X}^{\mathrm{b}}$ \\
\hline 372 & $\mathrm{X}^{\mathrm{a}}$ & $\mathrm{X}^{\mathrm{b}}$ \\
\hline 373 & - & $\mathrm{X}^{\mathrm{b}}$ \\
\hline 374 & $\mathrm{X}^{\mathrm{a}}$ & - \\
\hline 375 & $\mathrm{X}^{\mathrm{a}}$ & $\mathrm{X}^{\mathrm{b}}$ \\
\hline $424-451$ & - & $\mathrm{X}^{\mathrm{b}}$ \\
\hline $456-486$ & $\mathrm{X}^{\mathrm{a}}$ & - \\
\hline
\end{tabular}

ribotypes representing a higher number of discernible DNA-strands (Table 1). The presence of certain TRFs common to algal and reference surfaces (e.g. $71,127,248,315,371,375 \mathrm{bp}$ ) indicated that some bacterial types were not affected by algae. The algalassociated bacterial communities were characterized by the absence (e.g. 80, 128, 374 bp) or presence (e.g. $62,96-123,131-182 \mathrm{bp}$ ) of certain bacterial ribotypes compared to bacterial communities from reference sites (Table 1).

Based on the similarity analysis of 242 discernible TRFs (Table 2), the community profiles in biofilms harvested on artificial substrata (Petri dishes) in the Caulerpa habitat and alga-free control sites $50 \mathrm{~m}$ away were compared. These communities were characterized by the presence (e.g. 298, 472, 473 bp) or absence (e.g. 131, 181, 370-386, $484 \mathrm{bp}$ ) of bacterial ribotypes on Petri-dishes (Table 2). In general, bac- 


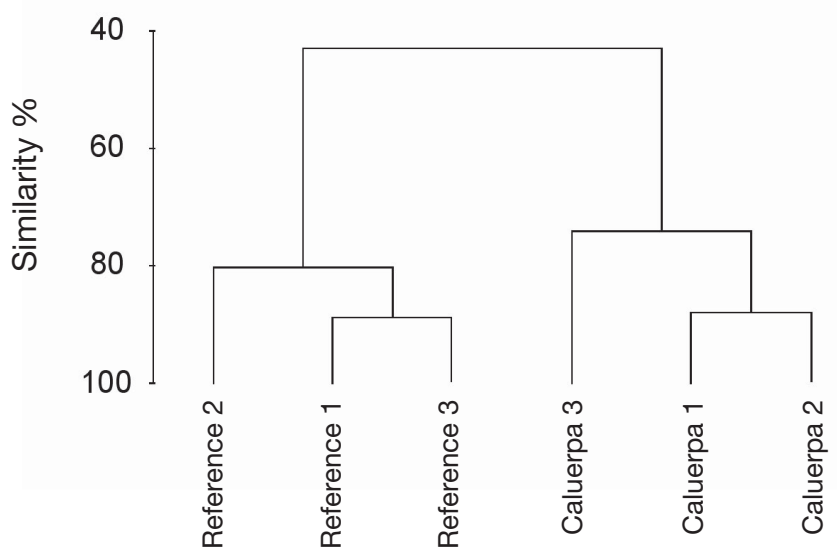

Fig. 2. Dendrogram compiled from cluster analyses of presence and absence of terminal restriction fragments (TRFs) in terminal restriction fragment length polymorphism profiles of epibiotic bacteria on green alga Caulerpa racemosa (Caulerpa: 1-3) in comparison to the epibiotic bacteria from a reference surface (Reference: 1-3). Experiments replicated 3 times denoted as 1, 2 and 3. Dendrogram constructed by using similarity matrices of TRFs of bacterial community DNA samples

terial communities developed in the Caulerpa stand were different from bacterial communities developed at alga-free control sites (Fig. 3).

\section{Inhibition of bacterial growth by metabolites of Caulerpa racemosa}

CCW did not inhibit growth of any of the 17 bacterial strains tested in disc diffusion assays. A control (AFSW) did not affect bacterial growth either. Similarly, neither surface-associated metabolites at $2 \times$ SLC nor a hexane control inhibited the growth of the bacterial strains. Dipping algal thalli in hexane did not have a significant effect on Caulerpa cell lyses.

\section{Influence of Caulerpa extracts on larval development and settlement}

CCW caused mortality of early trochophores of Hydroides elegans at the concentrations of $1 \times$, $0.5 \times$, and $0.1 \times \mathrm{CCW}$ (Fig. 4A: ANOVA, df $=4 ; F=12.3$, $\mathrm{p}<0.05)$. Less than $30 \%$ of $H$. elegans larvae developed normally to the nectochaete stage at the original $(1 \times)$ and $0.5 \times \mathrm{CCW}$ concentration (Fig. 4B: ANOVA, df $=4 ; F=18.5, \mathrm{p}<0.05)$. Diluted 100 -fold $(0.01 \times), C C W$ had no toxic effect on early trochophore larvae.

Larval settlement of Hydroides elegans induced by IBMX in the presence of different molecular fractions of CCW was different (Fig. 5A; ANOVA, df $=5 ; F=$
Table 2. Terminal restriction fragment length polymorphism profiles of bacterial communities derived from Petri dishes exposed to fouling in Caulerpa racemosa microhabitats for $24 \mathrm{~h}$ and from Petri dishes out of these stands as references. Presence and fragment sizes (bps) of individual terminal restriction fragments (TRFs) are denoted as follows: $\mathrm{X}_{1}{ }^{\mathrm{a}}$ : present in 3 out of 3 replicates; ${ }^{\text {b}}:$ present in 2 out of 3 replicates; presence in 1 out of 3 replicates omitted; -: absence of particular TRFs in a given biofilm

\begin{tabular}{|c|c|c|}
\hline $\begin{array}{l}\text { TRF } \\
\text { (bps) }\end{array}$ & Reference & Caulerpa \\
\hline 62 & - & $\mathrm{X}^{\mathrm{b}}$ \\
\hline 64 & $\mathrm{X}^{\mathrm{b}}$ & - \\
\hline 78 & $\mathrm{X}^{\mathrm{a}}$ & $\mathrm{X}^{\mathrm{b}}$ \\
\hline 80 & - & $\mathrm{X}^{\mathrm{b}}$ \\
\hline 91 & $\mathrm{X}^{\mathrm{b}}$ & - \\
\hline 92 & - & $\mathrm{X}^{\mathrm{b}}$ \\
\hline 127 & $\mathrm{X}^{\mathrm{b}}$ & - \\
\hline 128 & $\mathrm{X}^{\mathrm{a}}$ & $X^{a}$ \\
\hline 131 & $\mathrm{X}^{\mathrm{a}}$ & - \\
\hline 141 & $\mathrm{X}^{\mathrm{b}}$ & - \\
\hline 144 & - & $\mathrm{X}^{\mathrm{b}}$ \\
\hline 149 & $\mathrm{X}^{\mathrm{b}}$ & - \\
\hline 180 & $\mathrm{X}^{\mathrm{a}}$ & $\mathrm{X}^{\mathrm{b}}$ \\
\hline 181 & $\mathrm{X}^{\mathrm{a}}$ & - \\
\hline 182 & - & $\mathrm{X}^{\mathrm{b}}$ \\
\hline $184-269$ & $\mathrm{X}^{\mathrm{b}}$ & - \\
\hline 298 & - & $\mathrm{X}^{\mathrm{a}}$ \\
\hline 299 & $\mathrm{X}^{\mathrm{a}}$ & $\mathrm{X}^{\mathrm{b}}$ \\
\hline 311 & - & $\mathrm{X}^{\mathrm{b}}$ \\
\hline 321 & $\mathrm{X}^{\mathrm{b}}$ & - \\
\hline 367 & $\mathrm{X}^{\mathrm{a}}$ & $\mathrm{X}^{\mathrm{b}}$ \\
\hline 369 & $\mathrm{X}^{\mathrm{b}}$ & $\mathrm{X}^{\mathrm{a}}$ \\
\hline $370-386$ & $\mathrm{X}^{\mathrm{a}}$ & - \\
\hline 406 & $\mathrm{X}^{\mathrm{b}}$ & $\mathrm{X}^{\mathrm{b}}$ \\
\hline 457 & - & $\mathrm{X}^{\mathrm{b}}$ \\
\hline 472 & - & $\mathrm{X}^{\mathrm{a}}$ \\
\hline 473 & - & $\mathrm{X}^{\mathrm{a}}$ \\
\hline 474 & $\mathrm{X}^{\mathrm{a}}$ & $\mathrm{X}^{\mathrm{a}}$ \\
\hline 484 & $X^{a}$ & - \\
\hline 495 & - & $\mathrm{X}^{\mathrm{b}}$ \\
\hline
\end{tabular}

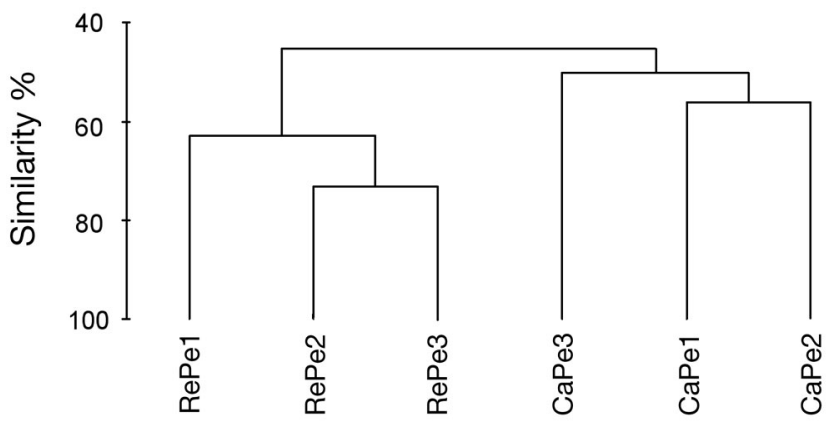

Fig. 3. Dendrogram compiled from cluster analyses of presence and absence of terminal restriction fragments (TRFs) in terminal restriction fragment length polymorphism profiles of epibiotic bacteria on Petri dishes exposed to dense assemblages of the green alga Caulerpa racemosa (CaPe1-3) in comparison to epibiotic bacteria from Petri dishes from a reference site (RePe1-3). Experiments replicated 3 times denoted as 1, 2 and 3. Dendrogram constructed by using similarity matrices of TRFs of bacterial community DNA samples 

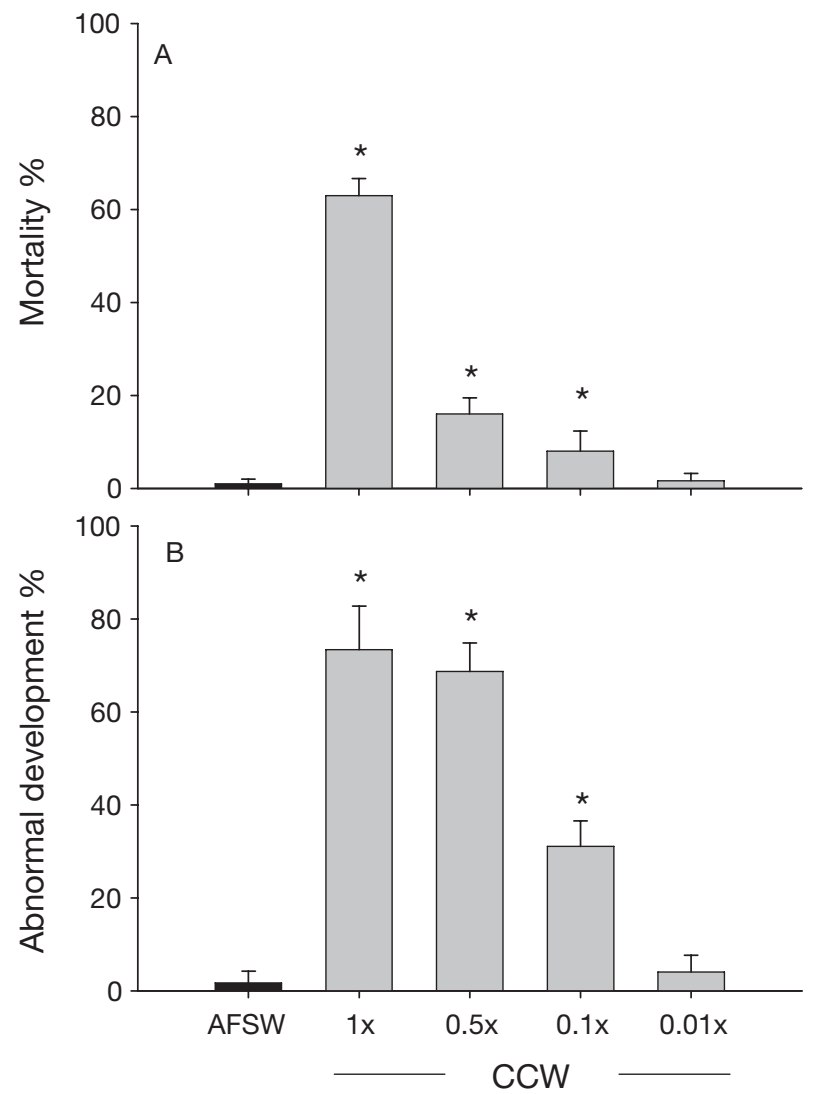

Fig. 4. Effect of Caulerpa racemosa conditioned seawater (CCW) and a dilution series on (A) survival of trochophore larvae and (B) larval development of early trochophore larvae of Hydroides elegans. Samples assayed under laboratory conditions together with controls $(0.22 \mu \mathrm{m}$-filtered and autoclaved seawater [AFSW]). Larvae treated with CCW for $24 \mathrm{~h}$. Data provide means of 3 batches done in 5 replicates \pm SD. * Significant statistical differences ( $p<0.05$, Dunnett's test) between the treatment and the controls

19.8, LSD: $\mathrm{p}<0.0001)$. Larval settlement in dishes containing $100 \mathrm{kD}, 100-10 \mathrm{kD}$ and $10-1 \mathrm{kD}$ filter residues of CCW was not different from that in AFSW (LSD: $p$ > $0.05)$, while settlement in dishes containing a fraction of $<1 \mathrm{kD}$ was significantly lower than that in other dishes (LSD: $p<0.01$ ). Similar results were obtained in bioassays with Bugula neritina (Fig. 5B). In both experiments, the fraction of $<1 \mathrm{kD}$ inhibited larval settlement, whereas a high molecular weight fraction had no effect on the settlement of larvae, except the 1-10 kD fraction for B. neritina (Fig. 5).

Surface attached metabolites at a concentration of $2 \times$ SLC significantly affected (ANOVA, $\mathrm{df}=5 ; F=8.3, \mathrm{p}<$ 0.05) Hydroides elegans larval settlement induced by IBMX when compared to the DMSO control $(54 \pm 2 \%$ and $74 \pm 5 \%$ of larval settlement, respectively). Other concentrations of surface attached metabolites did not have any effect on larval settlement.

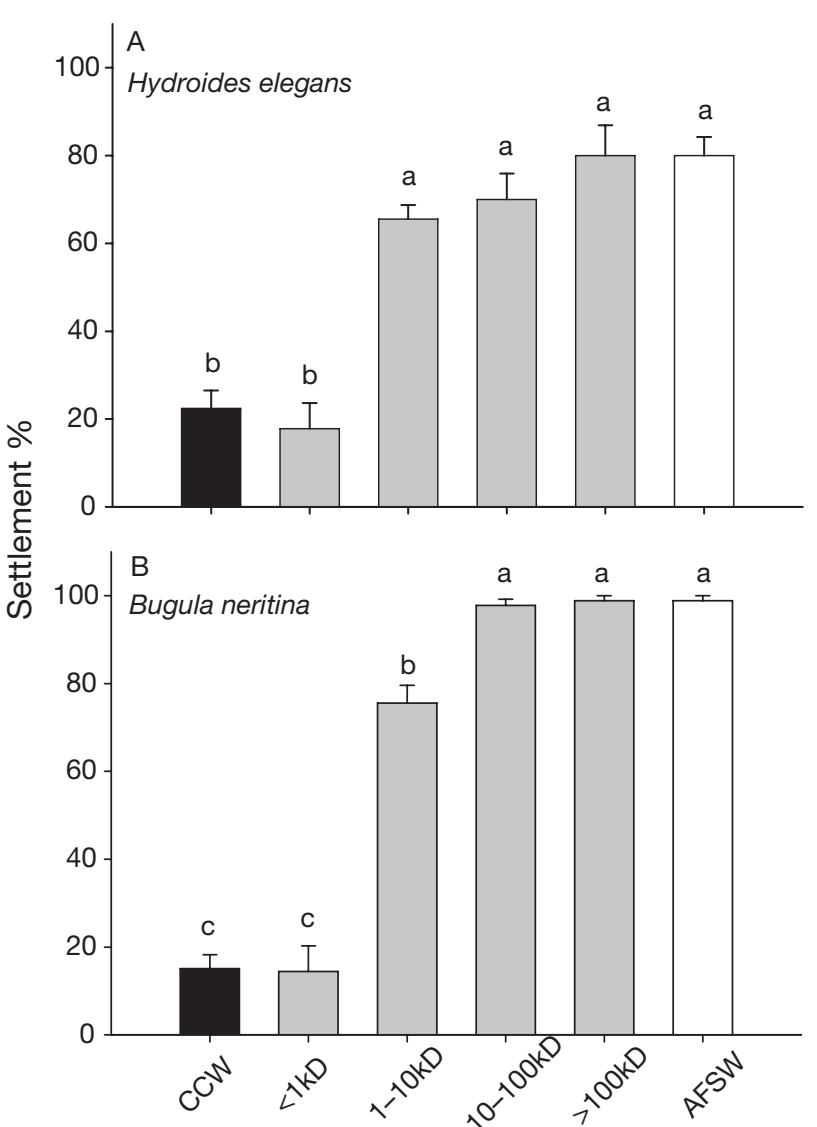

Fig. 5. Effect of Caulerpa racemosa conditioned seawater at non-toxic concentrations $0.01 \times$ (black bars) and molecular size fractions (grey bars) on larval settlement of (A) Hydroides elegans and (B) Bugula neritina. H. elegans larvae treated with $10^{-4} \mathrm{M} 3$-isobutyl-1-methylxanthine prior to experiment. Filtered $(0.22 \mu \mathrm{m})$ and autoclaved seawater (AFSW) used as controls (open bars). Percentage data of larval settlement are means \pm SD of 6 replicates. a, b, c: data that are significantly different (LSD post-hoc multiple comparison test, $\mathrm{p}<0.05$ )

At a concentration $\geq 0.012 \mathrm{mg} \mathrm{ml}^{-1}$ in AFSW, CYN inhibited Hydroides elegans larval settlement (Fig. 6A). Solutions of CYN in AFSW at the concentration of $0.06 \mathrm{mg} \mathrm{ml}^{-1}$ and higher were toxic to $H$. elegans larvae (Fig. 6B). CYN at the concentration of $0.006 \mathrm{mg}$ $\mathrm{ml}^{-1}$ was neither inhibitive nor toxic (Fig. 6).

\section{Identification of CYN}

The largest peak in the HPLC chromatogram of an ethanol extract from Caulerpa racemosa represented the compound CYN (indicated by an asterisk in Fig. 7A). The purity of the compound was verified by a comparison of the resultant mass spectrum (Fig. 7A) with published data in Jung \& Pohnert (2001). The hexane:ethyl acetate fraction and the ethyl acetate fraction of CCW did not reveal CYN in the chroma- 
tograms (Fig. 7B,C). GC-MS revealed the presence of CYN in the surface extracts of C. racemosa. A chromatographic dilution series experiment revealed the detection limit of CYN at $0.01 \mu \mathrm{g} \mathrm{ml}^{-1}$.

\section{DISCUSSION}

The abundance of epibiotic bacteria and diatoms on the frond surfaces of Caulerpa racemosa and in the biofilms developed on the reference substrata was similar as revealed by electron miscroscopic enumeration (Fig. 1). One explanation for this observation was the low physical renewal of epithelial algal tissue or surface sloughing (Wahl 1997, Nylund \& Pavia 2005). An alternative explanation was the possibility of a targeted chemical defense against certain microbial species, leading to a numerically similar but compositionally different microbial community profile in comparison to undefended substrates (Harder et al. 2003).
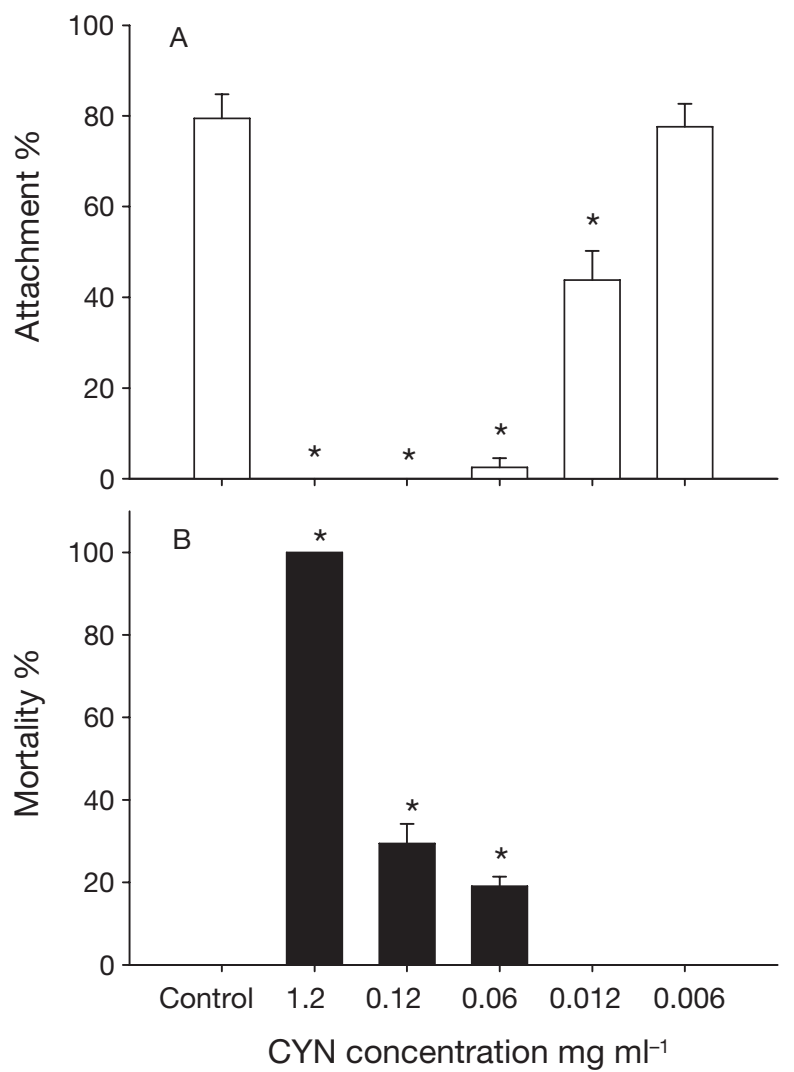

Fig. 6. Effect of caulerpenyne (CYN) on (A) larval settlement and (B) larval mortality of Hydroides elegans. Larvae treated with $10^{-4} \mathrm{M}$ 3-isobutyl-1-methylxanthine prior to experiment. Filtered $(0.22 \mu \mathrm{m})$ and autoclaved seawater used as control. Percentage data are means \pm SD of 6 replicates. ${ }^{*}$ Data that are significantly different (Dunnett's post-hoc multiple comparison test, $\mathrm{p}<0.05)$
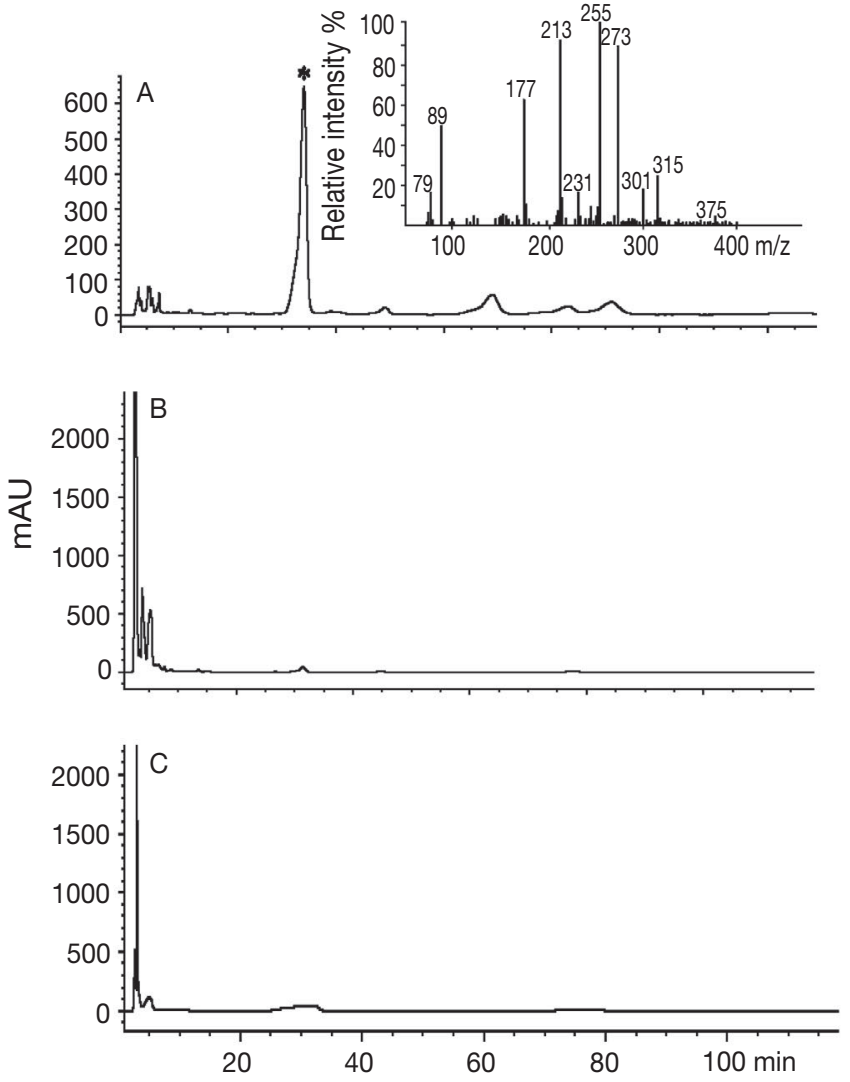

Fig. 7. Normal phase high performance liquid chromatograms of extracts of alga Caulerpa racemosa detected at $254 \mathrm{~nm}$. (A) Ethanol extract of C. racemosa. Insert shows EI mass spectrum of dominant metabolite caulerpenyne. (B) Hexane:ethyl acetate $(95: 5 \%)$ fraction of C. racemosa conditioned seawater. (C) Ethyl acetate $(100 \%)$ fraction of C. racemosa conditioned seawater

Cluster analysis of a similarity matrix demonstrated that the profiles of bacterial communities on replicate algal surfaces were highly similar, forming a cluster distantly related to bacterial communities on replicate reference surfaces. Since we assumed that the algae and the reference rock surfaces had been exposed to the same pool of bacterial colonizers at the experimental site, we hypothesized that the differences in the bacterial communities were the result of chemical alga-related attributes, such as inhibitory agents against bacterial epibiosis or nutritious agents for the enrichment of specific bacteria. The physical defenses, such as mucus production and sloughing of dead algal cells, may also have resulted in the formation of unique bacterial communities on the surface of the alga. However, we did not observe an antimicrobial effect of surface-attached and waterborne metabolites of Caulerpa racemosa on bacterial isolates from natural biofilms. This phenomenon could be due to the fact that bacteria may be affected by algal metabolites at any phase 
of the colonization process through different mechanisms. The measurement of inhibition zones in the disk-diffusion bioassay, indicating bacteriological or bacteriostatic effects, reflects only one mechanism (inhibition of bacterial growth) by which bacterial abundance can be affected. In the natural environment, algal metabolites may affect bacterial colonization through inhibition of growth, chemotaxis (repulsion), cell motility (spreading) and production of external polymers (attachment). For instance, antibacterial activities of compounds did not necessarily correlate to the prevention of bacterial attachment (Wahl et al. 1994, Boyd et al. 1999, Newbold et al. 1999, Kelly et al. 2003).

The high similarities of bacterial community profiles between algal surfaces were supposed to stem from the uniformity and a similar presence or absence of these attributes. Despite the limitation of the T-RFLP analysis in revealing the complexity of native bacterial communities at the species level (Heuer et al. 2001), the presence or absence of certain bacterial types in the algaassociated bacterial community in comparison to the supposedly ubiquitous bacterial colonizers in the control, indicated possible physical and chemical controlled anti-epibiotic effects of the alga. The observation of bacterial enrichment of certain bacterial types was not surprising when considering the nutritional value of algal exopolymeric secretions (Wotton 2004). Indeed, specific associations between macroalgae and bacteria have previously been shown in Caulerpa spp. (Meusnier et al. 2001, Delbridge et al. 2004) and other macroalgae (Egan et al. 2000, Dobretsov \& Qian 2002, Matsuo et al. 2003, Harder et al. 2004).

The results of the similarity analysis of the bacterial communities in the biofilms harvested from artificial substrata in the Caulerpa habitat and alga-free control sites $50 \mathrm{~m}$ away were in good accordance with the results obtained from algal and rock surface communities. Based on the similarity analysis of 242 discernible TRFs, the bacterial community profiles of the reference biofilms formed a cluster distantly related to the bacterial communities of biofilms on artificial surfaces in the C. racemosa stand. This suggested that algal waterborne metabolites play an important role in the formation of bacterial communities in the Caulerpa microhabitat.

The CCW and surface-attached metabolites did not inhibit bacterial growth in the disc diffusion assay, which could be attributed to several reasons. Firstly, a mechanical defense may be responsible for the formation of unique bacterial communities associated with this alga. Secondly, Caulerpa chemical compounds may have effects other than bactericidal that were not revealed in the disk-diffusion bioassay. Thirdly, the concentration of antibacterial waterborne and surface associated compounds (i.e. CYN) may have been too low to inhibit the bacterial growth in our experiment. However, CCW exhibited a toxic effect on Hydroides elegans larvae, or evoked abnormal larval metamorphosis in a concentration dependent fashion. At sublethal concentrations, the low molecular weight fraction $(<1 \mathrm{kDa})$ of CCW inhibited larval settlement of both $H$. elegans and Bugula neritina. Surface attached metabolites of this alga inhibited $H$. elegans settlement only at $2 \times$ SLC. These data suggested that waterborne metabolites are most likely responsible for antilarval defense in the macroalga Caulerpa racemosa.

We did not identify the prominent antimicrobial metabolite CYN (Dumay et al. 2002, Paul et al. 2006) in CCW. This finding may be due to either the absence of this compound in seawater or to the quick degradation of CYN in CCW (Amade \& Lemée 1998). It has been shown that $50 \%$ of CYN degrades after $4 \mathrm{~h}$ in seawater and only $5 \%$ of CYN remains after $24 \mathrm{~h}$ in seawater (Amade \& Lemée 1998). Our HPLC method identified CYN in seawater at concentrations as low as $0.01 \mu \mathrm{g}$ $\mathrm{ml}^{-1}$, while an effective inhibitive concentration of CYN against Hydroides elegans larvae was 1000× higher. This suggests that although CCW may contain some CYN the concentration was insufficient to have any biological effect on settling larvae of $H$. elegans. Thus, bioactive metabolites other than CYN seem to be responsible for the lack of settlement response of competent larvae and the toxic effects on pre-competent larvae of $H$. elegans. Interestingly, a similar result was observed by Amade \& Lemée (1998); these authors found that while CYN quickly degraded in seawater, this solution remained inhibitive to sea urchin egg cleavage. Further investigations are needed in order to pursue water-soluble antifouling compounds from Caulerpa and determine their concentrations as well as release rates under natural conditions.

Hypothetically, the optimal defense strategy of marine organisms would be to conserve energy and exude deterrent metabolites at or close to their surface (Jennings \& Steinberg 1997, Steinberg et al. 2001, 2002). However, highly water-soluble, polar metabolites, such as phlorotannins are increasingly discounted as effective natural antifouling agents due to their rapid dissolution from their host organisms (Jennings \& Steinberg 1997, Kubanek et al. 2004). Although the causative agents remain unidentified in our study, these arguments may need to be cautiously reconsidered in the light of these and our previous findings (Dobretsov \& Qian 2002, Harder et al. 2004). Water-soluble molecules may play an essential chemical ecological role in marine systems, thus exemplifying a distinct concept in comparison to prominent examples of other algal antifoulants (Steinberg et al. 1997, de Nys et al. 1998, Bhadury \& Wright 2004). 
Acknowledgements. We thank Mrs. Y. Plakhotnikova of Qian's laboratory for her assistance with bacterial cultures and help with the disc-diffusion bioassay. We acknowledge Ms. M. Tsoi and Ms. Y.K. Tam of the Coastal Marine Laboratory for their help in the molecular bacterial community fingerprinting. We thank Dr. P. Amade (France) for his useful suggestions in caulerpenyne isolation and Dr. L.M. Liao (Philippines) for his help in the identification of the alga. We also acknowledge 4 anonymous referees who made a significant contribution to the final form of the manuscript. The present study was supported by the RGC grants HKUST 6240/04M and CAG04/05.SC01 to P.-Y.Q.

\section{LITERATURE CITED}

Aguilar-Santos G (1970) Caulerpin, a new pigment from green algae of the genus Caulerpa. J Chem Soc 6:842-843

Amade P, Lemée R (1998) Chemical defense of the Mediterranean alga Caulerpa taxifolia: variations in caulerpenyne production. Aquat Toxicol 43(4):287-300

Amann RI, Krumholz L, Stahl DA (1990) Fluorescentoligonucleotide probing of whole cells for determinative, phylogenetic, and environmental studies in microbiology. J Bacteriol 1972:762-770

Bhadury P, Wright PC (2004) Exploitation of marine algae: biogenic compounds for potential antifouling applications. Planta 219:561-578

Blackwood CB, Marsh T, Kim SH, Paul EA (2003) Terminal restriction fragment length polymorphism data analysis for a quantitative comparison of microbial communities. Appl Environ Microbiol 69:926-932

Boyd KG, Mearns-Spragg A, Burgess JG (1999) Screening of marine bacteria for the production of microbial repellents using a spectrophotometric chemotaxis assay. Mar Biotechnol 1:359-363

Bryan JP, Rittschof D, Qian PY (1997) Settlement inhibition of bryozoan larvae by bacterial films and aqueous leachates. Bull Mar Sci 61:849-857

Buchan A, Newell SY, Butler M, Biers EJ, Hollibaugh JT, Moran MA (2003) Dynamics of bacterial and fungal communities on decaying salt marsh grass. Appl Environ Microbiol 69:6676-6687

Conover WJ, Iman L (1981) Rank transformations as a bridge between parametric and nonparametric statistics. Am Statist 35:124-129

Delbridge L, Coulburn J, Fagerberg W, Tisa LS (2004) Community profiling of bacterial endosymbionts in four species of Caulerpa. Symbiosis 37:335-344

De Nys R, Steinberg PD, Willemsen P, Dworjanyn SA, Gabelish CL, King RJ (1995) Broad spectrum effects of secondary metabolites from the red alga Delisea pulchra in antifouling assays. Biofouling 8:259-271

De Nys R, Dworjanyn SA, Steinberg PD (1998) A new method for determining surface concentrations of marine products on seaweeds. Mar Ecol Prog Ser 162:79-87

Devi P, Soilimabi W, D'Souza L, Sonak S, Kamat S, Singbal S (1997) Screening of some marine plant for activity against marine fouling bacteria. Bot Mar 40:87-91

Dobretsov S, Qian PY (2002) Effect of bacteria associated with the green alga Ulva reticulata on marine micro- and macrofouling. Biofouling 18:217-228

Dumay O, Pergent G, Pergent-Martini C, Amade P (2002) Variations in caulerpenyne contents in Caulerpa taxifolia and Caulerpa racemosa. J Chem Ecol 28(2):343-352

Dunbar J, Ticknor LO, and Kuske CR (2001) Phylogenetic specificity and reproducibility and new method for analy- sis of terminal restriction fragment profiles of 16S rRNA genes from bacterial communities. Appl Environ Microbiol 67:190-197

Egan S, Thomas T, Holmstrøm C, Kjelleberg S (2000) Phylogenetic relationship and antifouling activity of bacterial epiphytes from the marine alga Ulva lactuca. Environ Microbiol 2:343-347

Faulkner DJ (1995) Chemical riches from the ocean. Chem $\mathrm{Br}$ 31:680-684

Freile-Pelegrin Y, Morales JL (2004) Antibacterial activity in marine algae from the coast of Yucatan, Mexico. Bot Mar 47:140-146

Fusetani N (2004) Biofouling and antifouling. Nat Prod Rep 21:94-104

Harder T, Qian PY (2000) Waterborne compounds from the green seaweed Ulva reticulata as inhibitive cues for larval attachment and metamorphosis in the polychaete Hydroides elegans. Biofouling 16:205-214

Harder T, Lau SCK, Dobretsov S, Fang TK, Qian PY (2003) A distinctive epibiotic bacterial community on the soft coral Dendronephthya sp. and antibacterial activity of coral tissue extracts suggest a chemical mechanism against bacterial epibiosis. FEMS Microbiol Ecol 43:337-347

Harder T, Dobretsov S, Qian PY (2004) Waterborne polar macromolecules act as algal antifoulants in the seaweed Ulva reticulata. Mar Ecol Prog Ser 274:133-141

Hellio C, Bremer G, Pons AM, Le Gal Y, Bourgougnon N (2000) Inhibition of the development of microorganisms (bacteria and fungi) by extracts of marine algae from Brittany, France. Appl Microbiol Biotechnol 54:543-549

Hellio C, de La Broise D, Dufosse L, Le Gal Y, Bourgougnon N (2001) Inhibition of marine bacteria by extracts of macroalgae: potential use for environmentally friendly antifouling paints. Mar Environ Res 52:231-247

Hellio C, Marechal J-P, Veron B, Bremer G, Clare AS, Le Gal Y (2004) Seasonal variation of antifouling activities of marine algae from the Brittany Coast (France). Mar Biotechnol 6:67-82

Heuer HY, Wieland G, Schönfeld J, Schönwälder A, Newton NCM, Smalla K (2001) Bacterial community profiling using DGGE or TGGE analysis. In: Rochelle PA (ed) Environmental molecular microbiology: protocols and applications. Horizon Scientific Press, Wymondham, p 177-190

Jennings JG, Steinberg PD (1997) Phlorotannins versus other factors affecting epiphyte abundance on the kelp Ecklonia radiata. Oecologia 109:461-473

Jung V, Pohnert G (2001) Rapid wound-activated transformation of the green algal defensive metabolite caulerpenyne. Tetrahedron 57:7169-7172

Jung V, Thibaut T, Meinesz A, Pohnert G (2002) Comparison of the wound-activated transformation of caulerpenyne by invasive and noninvasive Caulerpa species of the Mediterranean. J Chem Ecol 28:2091-2105

Kelly S, Jensen PR, Henkell TP, Fenical W, Pawlik JR (2003) Effects of Caribbean sponge extracts on bacterial attachment. Aquat Microb Ecol 31:175-182

König G, Wright A (1997) Laurencia rigida: chemical investigations of its antifouling dichloromethane extract. J Nat Prod 60:967-970

Kubanek J, Lester S, Fenical W, Hay M (2004) Ambiguous role of phlorotannins as chemical defenses in the brown alga Fucus vesiculosus. Mar Ecol Prog Ser 277:79-93

Lee S, Malone C, Kemp PF (1993) Use of multiple 16S rRNAtargeted fluorescent probes to increase signal strength and measure cellular RNA from natural planktonic bacteria. Mar Ecol Prog Ser 101:193-201

Liu WT, Marsh TL, Cheng H, Forney LJ (1997) Characteriza- 
tion of microbial diversity by determining terminal restriction fragment length polymorphisms of genes encoding 16S rRNA. Appl Environ Microbiol 63:4516-4522

Luna GM, Dell'Anno A, Danovaro M (2006) DNA extraction procedure: a critical issue for bacterial diversity assessment in marine sediments. Environ Microbiol 8:308-320

Matsuo Y, Suzuki M, Kasai H, Shizuri Y, Harayama S (2003) Isolation and phylogenetic characterization of bacteria capable of inducing differentiation in the green alga Monostroma oxyspermum. Environ Microbiol 5:25-35

Meusnier I, Olsen JL, Stam WT, Destombe C, Valero M (2001) Phylogenetic analyses of Caulerpa taxifolia (Chlorophyta) and of its associated bacterial microflora provide clues for the origin of the Mediterranean introduction. Mol Ecol 10: 931-946

Meyer KD; Paul VJ (1992) Intraplant variation in secondary metabolite concentration in three species of Caulerpa (Chlorophyta: Caulerpales) and its effects on herbivorous fishes. Mar Ecol Prog Ser 82:249-257

Mtolera MSP, Semesi AK (1996) Antimicrobial activity of extracts from six green algae from Tanzania. In: Bjork M, Semesi AK, Pedersen M, Bergman B (eds) Current trends in marine botanical research in the East African region. Sida Department of Research Cooperation (SAREC), Stockholm, p 211-217

Newbold RW, Jensen PR, Fenical W, Pawlik JR (1999) Antimicrobial activity of Caribbean sponge extracts. Aquat Microb Ecol 19:279-284

Nylund GM, Pavia H (2003) Inhibitory effects of algal extracts on larval settlement of the barnacle Balanus improvisus. Mar Biol 143:875-882

Nylund GM, Pavia H (2005) Chemical versus mechanical inhibition of fouling in the red alga Delisea carnosa. Mar Ecol Prog Ser 299:111-121

Paul VJ, Fenical W (1986) Chemical defense in tropical green algae, order Caulerpales. Mar Ecol Prog Ser 34:157-169

Paul VJ, Puglisi MP, Ritson-Williams R (2006) Marine chemical ecology. Nat Prod Rep 23:153-180

Pechenik JA, Qian PY (1998) Onset and maintenance of metamorphic competence in the marine polychaete Hydroides elegans (Haswell) in response to 3 chemical cues. J Exp Mar Biol Ecol 226:51-74

Pedrotti ML, Lemée R (1999) Effect of microalgae treated with natural toxins on the nutrition and development of filterfeeding sea-urchin larvae. Mar Environ Res 3:177-192

Pesando D, Lemée R, Ferrua C, Amade P, Girard JP (1996) Effects of caulerpenyne, the major toxin from Caulerpa taxifolia on mechanisms related to sea urchin egg cleavage. Aquat Toxicol 35:139-155

Phillips DW, Towers GHN (1982) Chemical ecology of red algal bromophenols. I. Temporal, interpopulational and within-thallus measurements of lanosol levels in Rhodomela larix (Turner) C. Agardh. J Exp Mar Biol Ecol 58: 285-293

Schmitt T, Hay M, Lindquist N (1995) Constraints on chemically-mediated coevolution: Multiple functions for seaweed secondary metabolites. Ecology 76:107-123

Schroeder HC, Badria FA, Ayyad SN, Batel R, Wiens M, Hassanein HMA, Kurelec B, Mueller WEG (1998) Inhibitory effects of extracts from the marine alga Caulerpa toxifolia and of toxin from Caulerpa racemosa on multixenobiotic resistance in the marine sponge Geodia cydonium. Environ Toxicol Pharmacol 5:119-126

Selvi M, Selvaraj R (2000) Antibacterial activities of some Indian seaweeds. Seaweed Res Util 22:161-166

Smyrniotropoulos V, Abatis D, Tziveleka LA, Tsitsimpikou C, Roussis V, Loukis A, Vagias C (2003) Acetylene sesquiterpenoid esters from the green alga Caulerpa prolifera. J Nat Prod 66:21-24

Steinberg P, Schneider R, Kjelleberg S (1997) Chemical defenses of seaweeds against microbial colonization. Biodegradation 8:211-220

Steinberg P, De Nys R, Kjelleberg S (1998) Chemical cues for surface colonization. J Chem Ecol 28:1935-1951

Steinberg P, de Nys R, Kjelleberg S (2001) Chemical mediation of surface colonisation. In: McClintock JB, Baker BJ (eds). Marine chemical ecology. CRC Press, Boca Raton, FL, p 355-387

Steinberg P, de Nys R, Kjelleberg S (2002) Chemical cues for surface colonisation. J Chem Ecol 28:1935-1951

Wahl M (1997) Living attached: aufwuchs, fouling, epibiosis. In: Nagabhushanam R, Thompson MF (eds) Fouling organisms of the Indian Ocean: biology and control technology. AA Balkema, Rotterdam, p 31-83

Wahl M, Jensen PR, Fenical W (1994) Chemical control of bacterial epibiosis on ascidians. Mar Ecol Prog Ser 110: 45-57

Walters LJ, Hadfield MG, Smith CM (1996) Waterborne chemical compounds in tropical macroalgae: positive and negative cues for larval settlement. Mar Biol 126:383-393

Wotton RS (2004) The essential role of exopolymers in aquatic systems. Oceanogr Mar Biol Annu Rev 42:57-94

Zar JH (1999) Biostatistical analysis, 4th edn. Prentice-Hall, Upper Saddle River, NJ

Submitted: April 5, 2005; Accepted: December 14, 2005

Proofs received from author(s): July 13, 2006
Editorial responsibility: Otto Kinne (Editor-in-Chief), Oldendorf/Luhe, Germany 